Agustus 2006, Vol. 2, No. 3

Jurnal Penyuluhan

\title{
Persepsi dan Partisipasi Masyarakat Sasaran dalam Program Pengembangan Usaha Kelompok Kecil (Kasus Program Pengembangan Masyarakat PT Aneka Tambang, UPBE Pongkor di Desa Bantar Karet dan Desa Kalongliud, Kecamatan Nanggung Kabupaten Bogor, Jawa Barat)
}

\author{
Ahmad Fauzi $^{1}$, Dwi Sadono ${ }^{2}$ \\ ${ }^{1}$ Alumni Departemen Ilmu-Ilmu Sosial Ekonomi Pertanian, Institut Pertanian Bogor, Bogor \\ ${ }^{2}$ Departemen Sains Komunikasi dan Pengembangan Masyarakat, Institut Pertanian Bogor, Bogor
}

\begin{abstract}
Abstrak
Tujuan penelitian ini adalah untuk menganalisis persepsi dan partisipasi masyarakat dalam Program Pengembangan Usaha Kelompok Kecil (PUKK) sebagai salah satu program pengembangan masyarakat PT. Aneka Tambang UPBE Pongkor. Tujuan Jangka Panjang program PUKK diharapkan dapat mampu meningkatkan kemadirian masyarakat dalam pengembangan usaha di Kecamatan Nanggung pasca penambangan. Penelitin ini dilakukan di Desa Bantar Karet dan Kalongluid, Kecamatan Nanggung sebagai dua contoh lokasi pelaksanaan program PUKK. Jumlah responden adalah masyarakat sasaran penerima program PUKK sebanyak 27 orang yang berasal dari 19 kelompok sasaran penerima program PUKK. Masing-masing kelompok diambil secara acak sebanyak dua orang sementara apabila anggotanya hanya satu orang, maka diambil satu responden. Pengumpulan data dilakukan dengan metode survei dan wawancara terstruktur dalam bentuk kuesioner.

Persepsi masyarakat sasaran terhadap manfaat Program PUKK terdiri dari sepuluh indikator diranking berdasarkan skornya yang terdiri dari: (1) meningkatkan pendapatan masyarakat sasaran, (2) sesuai dengan kebutuhan masyarakat, (3) dapat dilaksanakannya pelatihan kewirausahaan, (4) program PUKK merupakan bentuk pinjaman lunak sebesar $4 \%$ per tahun, (5) mengatasi masalah permodalan usaha kecil di desa, (6) keberadaan konsultan dan pendamping dalam PUKK berguna sebagai transfer pengetahuan dan informasi bagi masyarakat sasaran, (7) mampu mengembangkan perekonomian desa,(8) PUKK secara tidak langsung dapat menciptakan lapangan kerja (9) menciptakan hubungan harmonis anatar perusahaan pertambangan dengan masyarakat setempat, (10) dapat membantu dalam pemasaran usaha kecil. Secara keseluruhan persepsi masyarakat sasaran terhadap manfaat program PUKK tergolong tinggi. Menurut responden, program PUKK sebagai implementasi program community developmentUPBE Pongkor, berupaya untuk menciptakan pertumbuhan ekonomi rakyat dan pemerataan pembangunan melalui perluasan kesempatan berusaha bagi usaha kecil masyarakat dan lingkungan sekitarnya, diindikasikan dengan peningkatan pendapatannya sehingga mampu menggerakkan perekonomian masyarakat Kecamatan Nanggung secara umum.

Partisipasi responden dalam penerapan program Pengembangan Usaha Kelompok Kecil (PUKK) yang diprogramkan oleh UPBE Pongkor, PT. Aneka Tambang, meliputi tahap perencanaan, pelaksanaan, pengawasan (evaluasi). Tingkat partisipasi masyarakat dalam program PUKK sebagian besar termasuk dalam kategori rendah.Rata-rata partisipasi responden pada tahap perencanaan masih termasuk tinggi. Tingginya partisipasi responden
\end{abstract}


Agustus 2006, Vol. 2, No. 3

\section{Jurnal Penyuluhan}

pada kegiatan perencanaan berhubungan erat dengan tingginya persepsi mereka terhadap manfaat program UPKK.

Partisipasi masyarakat sasaran dalam pelaksanaan PUKK tergolong rendah dibandingkan dengan rata-rata partisipasi. Sebagian besar usaha yang dijalankan oleh sasaran tidak sesuai dengan proposal yang diajukan ke tim PUKK UPBE Pongkor. Banyak sasaran yang beralih usaha lain, namun banyak usaha yang dijalankan oleh masyarakat sasaran mengalami kegagalan. Hal tersebut menurut responden disebabkan oleh pinjaman permodalan yang diperoleh dalam UPBE Pongkor rendah dibandingkan dengan kebutuhan usahanya. Selain itu,tingkat pengembalian pinjaman UKK juga tergolong rendah yaitu sekitar $10 \%$.Partisipasi masyarakat sasaran dalam evaluasi/monitoring yang meliputi kehadiran dan aktivitas dalam pertemuan evaluasi program PUKK dan peran evaluasi serta saran bagi program PUKK di tahun mendatang juga tergolong rendah.

Karakteristik individu responden yang berperan dengan persepsinya dalam program PUKK adalah tingkat pendidikan dan tingkat pendapatan. Sementara karakteristik umur dan pengalaman berwirausaha responden tidak berperan dengan persepsi terhadap manfaat program PUKK.Partisipasi responden dalam program PUKK dipengaruhi oleh karakteristik individu yaitu: umur, tingkat pendapatan dan pengalaman berwirausaha responden. Sementara partisipasi responden juga dipengaruhi oleh faktor eksternal yang terdiri atas penilaian responden tentang peranan tenaga konsultan, peranan pemerintah dan sarana prasarana yang diberikan oleh UPBE Pongkor dalam pengembangan usaha responden.

Persepsi responden berhubungn nyata dengan tingkat partisipasinya dalam program PUKK. Responden yang memiliki tinggi cenderung memiliki tingkat partisipasi yang tinggi pula, sebaliknya responden yang termasuk dalam kategori persepsi rendah cenderung mamiliki partisipasi yang rendah pula.

Partisipasi responden dalam program PUKK berhubungan nyata dengan perkembangan usahanya. Terdapat perbedaan diantara dua kelompok kategori partisipasi terhadap perkembanga usahanya. Responden yang berpartisipasi tinggi memiliki presentase perkembangan usaha yang lebih maju dibandingkan dengan responden yang tingkat partisipasinya rendah.

Rekomendasi kebijakan bagi perkembangan usaha kecil di Kecamatan Nanggung anatara lain: (1) perlu peningkatan partisipasi masyarakat terutama dalam pengambilan keputusan perencanaan PUKK, masyarakat sasaran yang diberikan kesempatan seluas-luasnya dalam pengambilan keputusan yang menyangkut kebijakan pelaksanaan PUKK, (2) perlu dibentuknya forum masyarakat sasaran sebagai media masyarakat sasaran menyalurkan aspirasinya dan sebagai kontrol bagi pelaksanaan program PUKK, (3) perlu adanya pembinaan yang sistematis dari berbagai stakeholder (UPBE Pongkor, pendamping, dan pemerintah) bagi perkembangan usaha kecil di Kecamatan Nanggung dalam bentuk: pemberian akses bahan baku usaha kecil, pelaksanaan pelatihan keterampilan yang relevan dan manajemen usaha kecil, perlu adanya tenaga pendamping sebagai mediasi transfer pengetahuan, penyediaan permodalan yang memadai dan akses pemasaran produk yang dihasilkan.

Kata kunci: persepsi, partisipasi, UPKK, UPBE Pongkor

\section{Pendahuluan}

Undang-undang No.1 Tahun 1967 tentang Penanaman Modal Asing (PMA) telah memacu pertumbuhan investasi berbagai sektor di dalam negeri termasuk pertambangan, sejak awal tahun 1970-1n 
Agustus 2006, Vol. 2, No. 3

\section{Jurnal Penyuluhan}

dengan dibukanya PMA maka industri pertambangan Indonesia mulai tumbuh pesat namun kondisi tersebut berubah drastis ketika terjadi krisis ekonomi pertengahan tahun 1997, permasalah sosial politik berimplikasi langsung pada iklim investasi sehingga tidak kondusif (Istiyar, 2003). Ketidaksiapan pemerintah dalam memenuhi tuntutan peningkatan sosial ekonomi masyarakat, pada akhirnya menempatkan pihak perusahaan (swasta) termasuk pertambangan, sebagai salah satu stakeholder yang menjadi "gantungan" terakhir, yang dianggap mampu mengatasi problematika yang ada. Hal itu mengakibatkan posisi perusahaan dalam kondisi yang dilematis. Fakta di lapangan seringkali memahami bahwa perusahaan memiliki kemampuan dan sumberdaya yang terbatas bagi solusi yang ada di tingkat komunitas. Ketidakjelasan antara hak dan kewajiban yang diemban oleh masing-masing pihak dan tidak adanya upaya untuk mengkomunikasikan hubungan yang disharmoni antara perushaan dan komunitas di sekitarnya (Lubis dkk, 2002).

Industri sebagai salah satu komponen dalam masyrakat, mempunyai kewajiban dan tanggungjawab sosial untuk mengembangkan kegiatan ekonomi masyarakat sekitarnya, oleh karena itu perlu perhatian industri terhadap masyarakat sekitar. Senbagai implementasi pemikiran tersebut, banyak perusahaan pertemabangan mengembangkan program pengembangan masyarakat (community development) terhadap masyarakat sekitar. Pada dasarnya pelaksanaan program pengembangan masyarakat (community development) industri pertambangan telah diatur oleh Pemerintah Pusat dalam Surat Keputusan meneteri keuangan No.316/KMK.616/1994 tanggal 27 Juni 1994 bahwa Badan Usaha Milik Negara (BUMN) harus menyisihkan maksimal 5\% dari keuntungannya untuk mengembangkan ekonomi masyarakat sekitar dalam bentk dana hibah untuk usaha kecil dan koperasi (Istiyar, 2000).

PT. Aneka Tambang, Unit Bisnis Pertambangan Emas Pongkor, sebagai salah satu perusahaan pertambangan mengembangkan program community development. Program pengembangan masyarakat dilakukan oleh PT. Aneka Tambang adalah pengembangan Usaha Kelompok Kecil (PUKK). Bentuk konkrit program PUKK adalah bantuan pinjaman modal bagi kelompok usaha kecil yang berada di Kecamatan Nanggung.

Program PUKK diharapkan mampu berdampak positif terhadap pengembangan usaha kecil dan peningkatan kesejahteraan hidup masyarakat. Program PUKK nantinya diharapkan masyarakat mampu hidup secara mandiri dan mengurangi ketergantungan masyarakat terhadap PT Aneka Tambang, sehingga ketika pasca pertambangan emas masyarakat mampu sejahtera. Akhirnya akan tercipta hubungan timbal balik yang harmonis antara masyarakatsekitar dengan pihak perusahaan pertambangan.

Program PUKK yang dirancang oeh PT Aneka Tambang tidka akan mencapai tujuan dengan baik tanpa persepsi poritif dan partisipasi aktif dari masyarakat setempat. Masyarakat pada prinsipnya harus diposisikan sebagai subyek atau ator utama program pengembangan masyarakat yang ikut berpartisipasu dalam merencanakan, mengimplementasi,

mengevaluasi/monitoring dan menikmati hasil program pengembangan masyarakat. Persepsi dan partisipasi masyarakat sasaran dalam program PUKK dapat berpengaruh bagi pengembangan usaha kecil di Kecamatan Nanggung. 
Agustus 2006, Vol. 2, No. 3

\section{Jurnal Penyuluhan}

Kajian persepsi dan partisipasi program pengembangan masyarakat industri pertambangan masih jarang dilakukan. Kajian pengembagan masyarakat atau lebih spesifik yang membahas tingkat partisipasi masyarakat yang banyak silakukan lebih menyoroti tentang persepsi dan tingkat partisipasi program pemberdayaan masyarakat yang dirancang oleh pemerintah dalam upaya menanggulangi kemiskinan. Berdasarkan hal tersebut maka penelitian ini bertujuan untuk (1) menganalisis persepsi masyarakat sasaran terhadap program PUKK, (2) menganalisis tingkat partisipasi masyarakat sasaran terhadap program PUKK, (3) menganalisis faktor-faktor internal dan eksternal yang dapat mempengaruhi persepsi dan partisipasi masyarakat sasaran terhadap program PUKK, dan (4) menganalisis hubungan persepsi masyarakat terhadap manfaat program PUKK dan tingkat partisipasinya dalam program PUKK.

\section{Metode Penelitian}

Penelitian ini dilakukan di dua desa yaitu: Desa Bantar Karet dan Desa Kalongliud, Kecamatan Nanggung, Kabupaten Bogor Provinsi Jawa Barat. Populasi pebelitian ini adalah masyarakat (masyarakat sasaran) penerima pinjaman modal usaha program Pengembangan Usaha Kecil (PUKK). Metode pengambilan sampel secara acak dari dua masyarakat sasaran, kecuali masyarakat yang tidak memiliki anggota, hanya satu orang. Jumlah responden di dua desa tersebut diambil sebanyak 27 orang. Sementara untuk mendukung analisis persepsi dan partisipasi, denga menentukan informan, baik pihak PT. Aneka Tambang maupun pemerintah desa, aparat kecamatan dan konsultan mengenai program PUKK. Pengolahan dan analisis data dilakukan dengan uji rank Spearman(Singarimbun dan Effendy, 1989).

\section{Hasil dan Pembahasan}

\section{Gambaran Umum Lokasi Penelitian}

Lokasi penelitian yaitu di Desa Bantar Karet dan Desa Kalongliud yang terletak di Kecamatan Nanggung. Mayoritas kedua lokasi penelitian menggunakan lahan milik sebagai sawah dan ladang (Desa Bantar karet sebesar 26,8\% sedangkan Desa Kalongliud sebesar $7227 \%)$. Mayoritas $(66,47 \%)$ pendidikan masyarakat di kedua desa tergolong rendah yaitu sampai tingkat SD. Dari segi mata pencaharian terdapat perbedaan, mayoritas 5814\%) masyarakat Desa bantar Karet bermatapencaharian sebagai petani sedangkan mayoritas $(50,08 \%)$ masyarakat Desa kalongluid bermatapencaharian sebagai pedagang.

Sejarah pertambangan emas Pongkor diawali tahn 1979 oleh tim geologi PT. Aneka Tambang tentang logam berat, kemudian ditahun 1980 dilanjutkan oleh penelitiab dan akhirnya dilakukan eksploitasi pad atahun 1988. Hubungan UPBE Pongkor dengan masyarakat sekitar telah terbina sejak tahun 1988 dalam proses penjajagan lokasi. Perkembangan selanjutnya pada tahun 1988-1989 terdapat usaha-usaha dari UPBE Pongkor untuk mendapatkan lahan strategis bagi pembangunan proyek. Usaha itu diwujudkan dalam bentuk pemebebasan tanah. Negosiasi lahan bersifat alot berkaitan dengan harga yang pantas, masyarakat menghendaki agar tanah yang akan dibebaskan di atas harga tanah yang akan dibebaskan di atas harga pasar yang berlaku kala itu. Manurut laporan Tahunan 
Agustus 2006, Vol. 2, No. 3

\section{Jurnal Penyuluhan}

Antam (1997) pembangunan pabrik dilakukan padatahun 1993 dan produksi komersial dilakukan pada bulan Me 1994. Pengembangan Pongkor dilakukan bulan Mei 1994. Pengembangan Pongkor diselesaikan pada bulan Nopember 1997 yang direncanakan mampu meningkatkan kapasitas prosuksi menjadi sekitar 5 ton emas per tahun.

Adanya kegiatan penambangan emas UPBE Pongkor mendapat sorotan dari masyarakat. Masalah yang sering muncul adalah kegiatan penambangan emas tanpa ijin (PETI). Pada tahun 1997 jumlah PETI berfluktuasi hingga mencapai $70 \%$ dari seluruh penambang yangmerambah wilayah Pongkor (sekitar 9000 pekerja terdiri jawara/penambang dan buruh angkut galian. Pada tahun 2000, jumlah PETI yang beroperasi di tambang emas Pongkor berkurang hingga menjadi sekitar 200 orang. Hubungan Masyarakat UPBE Pongkor membentuk divisi Community Development (Comdev) untuk mengurangi jumlah PETI dan meningkatkan kesejahteraan masyarakat setempat. Program pengembangan yang dilakukan oleh Divisi Comdev antara lain: pembangunan sarana dan prasarana umum, bantuan pembangunan tempat ibadah, pemberian bantuan pendidikan, pelatihan pertanian dan pembinan usaha kelompok kecil (PUKK) serta operasi.

Pada tahun 2001, tim PUKK UPBE Pongkor menyalurkan dana PUKK kelompok kecl di Kecamatan Nanggung dan sekitarnya sebesar Rp 693.500.000,00 (enam ratus sembilan puluh tiga juta lima ratus ribu rupiah). Mekanisme pelaksanaan PUKK di tingkat desa dilakukan dalam beberapa tahap yaitu (1) tingkat sosialisasi tim PUKK di tingkat desa, (2) pertemuan tim PUKK UPBE Pongkor dengan masyarakat sasaran, (3) pembentukan kelompok sasaran, (4) penentuan usaha produktif, (5) penyaluran pinjaman modal di UPBE Pongkor.

\section{Persepsi dan Partisipasi Masyarakat Sasaran terhadap Program Pengembangan Usaha Kelompok Kecil (PUKK)}

Persepsi masyarakat sasaran terhadap manfaat Program PUKK terdiri dari sepuluh indikator diranking berdasarkan skornya yang terdiri dari: (1) meningkatkan pendapatan masyarakat sasaran, (2) sesuai dengan kebutuhan masyarakat, (3) dapat dilaksanakannya pelatihan kewirausahaan, (4) program PUKK merupakan bentuk pinjaman lunak sebesar 4\% per tahun, (5) mengatasi masalah permodalan usaha kecil di desa, (6) keberadaan konsultan dan pendamping dalam PUKK berguna sebagai transfer pengetahuan dan informasi bagi masyarakat sasaran, (7) mampu mengembangkan perekonomian desa,(8) PUKK secara tidak langsung dapat menciptakan lapangan kerja (9) menciptakan hubungan harmonis anatar perusahaan pertambangan dengan masyarakat setempat, (10) dapat membantu dalam pemasaran usaha kecil. Secara keseluruhan persepsi masyarakat sasaran terhadap manfaat program PUKK tergolong tinggi. Menurut responden, program PUKK sebagai implementasi program community development $\mathrm{UPBE}$ Pongkor, berupaya untuk menciptakan pertumbuhan ekonomi rakyat dan pemerataan pembangunan melalui perluasan kesempatan berusaha bagi usaha kecil masyarakat dan lingkungan sekitarnya, diindikasikan dengan peningkatan pendapatannya sehingga mampu menggerakkan perekonomian masyarakat Kecamatan Nanggung secara umum.

Partisipasi responden dalam penerpan program Pengembangan Usaha 
Agustus 2006, Vol. 2, No. 3

\section{Jurnal Penyuluhan}

Kelompok Kecil (PUKK) yang diprogramkan oleh UPBE Pongkor, PT. Aneka Tambang, meliputi tahap perencanaan, pelaksanaan, pengawasan (evaluasi). Tingkat partisipasi masyarakat dalam program PUKK sebagian besar termasuk dalam kategori rendah.

Partisipasi responden dalam program PUKK diklasifikasikan ke dalam dua kategori, yaitu: kategori rendah dan kategori tinggi. Pengelompokan tersebut ditentukan berdasarkan rata-ratanya (nilai tengah) dan distribusi partisipasi responden dalam PUKK (Tabel 1).

Tabel 1. Kategori Tingkat Partisipasi Responden dalam program PUKK

\begin{tabular}{|l|l|l|l|l|}
\hline \multirow{2}{*}{ Kategori } & \multicolumn{2}{|c|}{ Partisipasi } & Jumlah & $\begin{array}{l}\text { Persen } \\
(\%)\end{array}$ \\
\cline { 2 - 3 } & Skor & $\begin{array}{l}\text { Rata- } \\
\text { rata }\end{array}$ & & \\
\hline Rendah & $<1,52$ & 1,24 & 16 & 59,26 \\
\hline Tinggi & $\geq 1,52$ & 1,93 & 11 & 40,74 \\
\hline Jumlah & 27 & 100,00 \\
\hline
\end{tabular}

Pada dasarnya, persepsi responden dipengaruhi oleh pengetahuannya terhadap program PUKK, hal tersebut seuai dengan pendapat yang dikemukakan oleh Mar'at (1984) seperti dikutip Endaryanto (1999) bahwa pembentukan persepsi pada diri individu yang dipengaruhi oleh faktor lingkungan seperti pendidikan, lingkungan sosial, serta status dalam masyarakat. Sementara tingkat pengetahuan responden tidak dipengaruhi oleh umur sehingga tidak terdapat perbedaan persepsi yang nyata antar kelompok umur muda dan tua dalam indikator manfaat program PUKK.

Rata-rata partisipasi responden pada tahap perencanaan masih termasuk tinggi. Tingginya partisipasi responden pada kegiatan perencanaan berhubungan erat dengan tingginya persepsi mereka terhadap manfaat program UPKK. Adanya dorongan mereka berperan aktif dalam menghadiri undangan dari UPBE Pongkor yang dilaksanakan di masing-masing desa. Rapat undangan kedua mereka hadir dalam pengambilan uang pinjaman PUKK di UPBE Pongkor.

Partisipasi masyarakat sasaran dalam pelaksanaan PUKK tergolong rendah dibandingkan dengan rata-rata partisipasi. Hal ini relevan dengan pendapat Sahidu (1998) yang menyatakan bahwa partisipasi masyarakat dipengaruhi oleh kemauan, kemampuan dan kesempatan. Sebagian besar usaha yang dijalankan oleh sasaran tidak sesuai dengan proposal yang diajukan ke tim PUKK UPBE Pongkor. Banyak sasaran yang beralih usaha lain, namun banyak usaha yang dijalankan oleh masyarakat sasaran mengalami kegagalan. Hal tersebut menurut responden disebabkan oleh pinjaman permodalan yang diperoleh dalam UPBE Pongkor rendah dibandingkan dengan kebutuhan usahanya. Selain itu,tingkat pengembalian pinjaman UKK juga tergolong rendah yaitu sekitar $10 \%$.

Partisipasi masyarakat sasaran dalam evaluasi/monitoring yang meliputi kehadiran dan aktivitas dalam pertemuan evaluasi program PUKK dan peran evaluasi serta saran bagi program PUKK di tahun mendatang juga tergolong rendah.

Karakteristik individu responden yang berperan dengan persepsinya dalam program PUKK adalah tingkat pendidikan dan tingkat pendapatan. Sementara karakteristik umur dan pengalaman berwirausaha responden tidak berperan dengan persepsi terhadap manfaat program PUKK.

\begin{tabular}{cccr}
\multicolumn{2}{c}{ Partisipasi } & responden & dalam \\
program & PUKK & dipengaruhi & oleh
\end{tabular} karakteristik individu yaitu: umur, tingkat pendapatan dan pengalaman berwirausaha responden. Sementara partisipasi 
Agustus 2006, Vol. 2, No. 3

\section{Jurnal Penyuluhan}

responden juga dipengaruhi oleh faktor eksternal yang terdiri atas penilaian responden tentang peranan tenaga konsultan, peranan pemerintah dan sarana prasarana yang diberikan oleh UPBE Pongkor dalam pengembangan usaha responden.

\section{Hubungan Karakteristik Sosial Ekonomi Responden dengan Persepsi dan Partisipasi dalam Program UKK}

Terdapat dua varasi diantara dua kategori pendidikan dalam penyusun ranking manfaat PUKK, seperti indikator meningkatkan pendapatan dan membantu dalam pemasaran industri kecil mereka menempatkan pada ranking yang sama masing-masing pada ranking kelima dan kesepuluh. Sepuluh indikator manfaat program PUKK lainnya tidak menunjukkan ranking yang sama. Terdapat perbedaan dalam menentukan ranking diantara dua kategori pendidikan. Rangking manfaat tersebut diterima oleh kedua kelompok kategori pendidikan, terbukti pada nilai korelasi rank Spearman (taraf nyata 5\%). Ditinjau dari korelasi peringkat, kedua kategori responden mempunyai kesesuaian yang sangat kuat dalam menentukan ranking indikator manfaat program.

Semakin tinggi tinggi pendapatan responden cenderung memiliki persepsi positif terhadap manfaat program UKK (Tabel 2). Pada peubah tingkat pendapatan, mengindikan bahwa semakin tinggi pendapatan responden berarti akan meningkatkan kesejahteraan komunitas, akan makin positif persepsinya tentang manfaat PUKK, harapan untuk memperoleh pendapatan yang memadai merupakan harapan responden di sekitar kawasan UPBE Pongkor.
Tabel 2. Hubungan Karakteristik Responden dan Persepsi dan Partisipasi terhadap Manfaat Program PUKK

\begin{tabular}{|l|l|l|l|l|l|}
\hline No. & $\begin{array}{l}\text { Karakteristik } \\
\text { Responden }\end{array}$ & \multicolumn{2}{|c|}{ Persepsi } & \multicolumn{2}{c|}{ Partisipasi } \\
\hline & r hitung & $\begin{array}{l}\mathrm{r} \\
\text { tabel }\end{array}$ & $\mathrm{r}$ hitung & $\mathrm{r}$ tabel \\
\hline 1 & Umur & 0,263 & 0,648 & $0,742^{*}$ & 0,648 \\
\hline 2 & Pendidikan & $0,652^{*}$ & 0,648 & 0,636 & 0,648 \\
\hline 3 & $\begin{array}{l}\text { Pengalaman } \\
\text { berwirausaha }\end{array}$ & 0,073 & 0,648 & $0,830^{* *}$ & 0,794 \\
\hline 4 & $\begin{array}{l}\text { Tingkat } \\
\text { pendapatan }\end{array}$ & $0,818^{*} *$ & 0,794 & $0,912^{* *}$ & 0,794 \\
\hline
\end{tabular}

nyata pada taraf $1 \%$

Persepsi responden berhubungan nyata dengan tingkat partisipasinya dalam program PUKK. Responden yang memiliki tinggi cenderung memiliki tingkat partisipasi yang tinggi pula, sebaliknya responden yang termasuk dalam kategori persepsi rendah cenderung memiliki partisipasi yang rendah pula.

Semakin tua umur responden cenderung semakin tinggi tingkat partisipasinya dalam program PUKK. Hal tersebut sesuai dengan pendapatan Powel (1983) seperti dikutip oleh Susiatik (1998) sehingga meningkatkan partisipasinya dalam program.Partisipasi responden dalam program PUKK berhubungan nyata dengan perkembangan usahanya. Terdapat perbedaan diantara dua kelompok kategori partisipasi terhadap perkembanga usahanya. Responden yang berpartisipasi tinggi memiliki presentase perkembangan usaha yang lebih maju dibandingkan dengan responden yang tingkat partisipasinya rendah.

\section{Kesimpulan}

Persepsi masyarakat sasaran terhadap manfaat program UPKK tergolong tinggi, karena dengan harapan program PUKK mampu meningkatkan pendapatan mereka yang berpengaruh pada 
Agustus 2006, Vol. 2, No. 3

\section{Jurnal Penyuluhan}

perkembangan perekonomian masyarakat Kecamatan Nanggung

Partisipasi masyarakat sasaran
dalam perencanaan program tegolong tinggi, hal tersebut disebabkan oleh motivasi untuk mendapatkan dana PUKK sebagai permodalan menjalankan usahanya. Partisipasi masyarakat sasaran dalam pelaksanaan tergolong rendah yang disebabkan oleh rendahnya modal yang diterima masyarakat sasaran dibandingkan dengan kebutuhan modal usahanya. Tingkat partisipasi dalam evaluasi juga rendah, karena UPBE Pongkor tidak memberikan kesempatan kepada masyarakat untuk berpartisipasi. Secara umum partisipasi masyarakat dalam program PUKK masih rendah dan belum mencerminkan prinsip-prinsip pengembangan masyarakat (community development).

Karakteristik individu responden yang berperan penting dalam pembentukan persepsinya dlaam program PUKK adalah pendidikan dan tingkat pendapatan. Sementara karakteristik umur dan pengalaman berwirausaha responden tidak berperan dalam manfaat program PUKK. Rendahnya partisipasi responden dalam program PUKK disebabkan oleh fktor internal dan faktor eksternal. Faktor internal individu yang berhubungan dengan partisipasi responden dalam program PUKK adalah umur, tingkat pendapatan, dan pengalaman berwirausaha reponde. Karakteristik tingkat pendidikan tidak berhubungan dengan partisipasi responden dalam program PUKK. Sementara faktor eksternal yang terdiri atas: penilaian responden tentang peranan tenaga konsultan, peranan pemerintah dan sarana prasarana yang diberikan oleh UPBE Pongkor dalam pengembangan usaha responden, berhubungan dengan partisipasi responden dalam PUKK.
Persepsi masyarakat sasaran mempengaruhi tingkat partisipasinya dalam program PUKK. Responden yang memiliki persepsi tinggi cenderung memiliki tingkat partisipasi yang tinggi pula, sebaliknya responden yang termasuk kategori rendah cenderung memiliki partisipasi yang rendah pula. Partisipasi masyarakat dalam program PUKK berperan bagi perkembangan usahanya. Terdapat perbedaan di antara dua kelompok kategori partisipasi terhadap perkembangan usahanya. Secara umum perkembangan usaha yang dijalankan oleh masyarakat sasaran mengalami kegagalan disebabkan oleh rendahnya tingkat partisipasinya dalam prgram PUKK.

\section{Daftar Pustaka}

Endaryanto. 1998. Persepsi dan Partisipasi Masyarakat yang Terlibat dan Tidak Terlibat Program Makanan Tambahan Anak Sekolah (PMT-AS). [Tesis]. Bogor (ID): Institut Pertanian Bogor.

Lubis DP, dkk. 2002. Profil Desa Gunung Putri. Studi Perencanaan Pengembangan Masyarakat di sekitar Kawasan Industri PT. Indocement Tunggal Prakarsa (PT ITP) Tbk. Kerjasama PT. ITP, Tbk dengan Pusat Penelitian Lingkungan Hidup (PPLH) . Bogor (ID): Institut Pertanian Bogor.

Sahidu A. 1998. Partisipasi Masyarakat Tani Pengguna Lahan Sawah dalam Pembangunan Pertanian di Daerah Lombok, Nusa Tenggara barat. [Disertasi]. Bogor (ID): Institut Pertanian Bogor.

Susiatik T. 1998. Persepsi dan Partisipasi Masyarakat terhadap kegiatan Pembangunan Masyarakat Desa Hutan Terpadu (PMDHT) di Desa Mojorebo Kecamatan Wirosari 
Agustus 2006, Vol. 2, No. 3

Kabupaten Grobogan Jawa tengah.

[Tesis]. Bogor (ID): Institut

Pertanian Bogor.

Singarimbun M, Effendi S. 1989. Metode

penelitian survei. Jakarta (ID):

LP3ES. 